\title{
A derivative of the D5 monoclonal antibody that targets the gp41 N-heptad repeat of HIV-1 with broad tier-2 neutralizing activity
}

Adonis A. Rubio ${ }^{1}$, Maria V. Filsinger Interrante ${ }^{2,3,8}$, Benjamin N. Bell ${ }^{4,8}$, Clayton L. Brown ${ }^{5,8}$, Celia C. LaBranche ${ }^{6,7}$, David C. Montefiori ${ }^{6,7}$, Peter S. Kim ${ }^{5,8,9 *}$

${ }^{1}$ Department of Biology, Stanford University School of Humanities \& Sciences, Stanford, CA 94305, USA

${ }^{2}$ Stanford Biophysics Program, Stanford University School of Medicine, Stanford, CA 94305, USA

${ }^{3}$ Stanford Medical Scientist Training Program, Stanford University School of Medicine, Stanford, CA, 94305, USA

${ }^{4}$ Department of Molecular and Cellular Physiology, Stanford University School of Medicine, Stanford, CA 94305, USA

${ }^{5}$ Department of Biochemistry, Stanford University School of Medicine, Stanford, CA 94305, USA

${ }^{6}$ Department of Surgery, Duke University Medical Center, Durham, NC 27710, USA

${ }^{7}$ Duke Human Vaccine Institute, Duke University Medical Center, Durham, NC 27710, USA

${ }^{8}$ Stanford ChEM-H, Stanford University, Stanford, CA 94305, USA

${ }^{9}$ Chan Zuckerberg Biohub, San Francisco, CA 94158, USA

*Corresponding Author: Peter S. Kim

e-mail: kimpeter@stanford.edu 


\begin{abstract}
$\underline{\text { Abstract }}$
HIV-1 infection is initiated by the viral glycoprotein Env, which, after interaction with cellular coreceptors, adopts a transient conformation known as the pre-hairpin intermediate (PHI). The N-heptad repeat (NHR) is a highly conserved region of gp41 exposed in the PHI; it is the target of the FDA-approved drug enfuvirtide and of neutralizing monoclonal antibodies (mAbs). However, to date these mAbs have only been weakly effective against tier-1 HIV-1 strains, which are most sensitive to neutralizing antibodies. Here, we engineered and tested $11 \mathrm{IgG}$ variants of D5, an anti-NHR mAb, by recombining previously described mutations in four of D5's six antibody complementarity-determining regions. One variant, D5_AR, demonstrated 6-fold enhancement in $\mathrm{ID}_{50}$ against lentivirus pseudotyped with HXB2 Env. Importantly, D5_AR exhibited weak cross-clade neutralizing activity against a diverse set of tier-2 HIV-1 viruses, which are less sensitive to neutralizing antibodies than tier-1 viruses and are the target of current antibody-based vaccine efforts. In addition, the neutralization potency of D5_AR IgG was greatly enhanced in target cells expressing Fc $\gamma \mathrm{RI}$ with $\mathrm{ID}_{50}$ values below $0.1 \mu \mathrm{g} / \mathrm{mL}$; this immunoglobulin receptor is expressed on macrophages and dendritic cells, which are implicated in the early stages of HIV-1 infection of mucosal surfaces. D5 and D5_AR have equivalent neutralization potency in $\mathrm{IgG}, \mathrm{Fab}$, and scFv formats, indicating that neutralization is not impacted by steric hindrance. Taken together, these results provide support for vaccine strategies that target the PHI by eliciting antibodies against the gp41 NHR.
\end{abstract}




\section{Importance}

Despite advances in anti-retroviral therapy, HIV remains a global epidemic and has claimed more than 32 million lives. Accordingly, developing an effective vaccine remains an urgent public health need. The gp41 N-heptad repeat (NHR) of the HIV-1 pre-hairpin intermediate (PHI) is highly conserved (>90\%) and is inhibited by the FDA-approved drug enfuvirtide, making it an attractive vaccine target. However, to date NHR antibodies have not been potent. Here, we engineered D5_AR, a more potent variant of the anti-NHR antibody D5, and established its ability to inhibit HIV-1 strains that are more difficult to neutralize and are more representative of circulating strains (tier-2 strains). The neutralizing activity of D5_AR was greatly potentiated in cells expressing Fc $\gamma R I$; Fc $\gamma$ RI is expressed on cells that are implicated at the earliest stages of sexual HIV-1 transmission. Taken together, these results bolster efforts to target the gp41 NHR and the PHI for vaccine development. 


\section{$\underline{\text { Introduction }}$}

Over 35 million people currently live with HIV/AIDS globally (1); despite the promise of anti-retroviral therapy, a preventative HIV-1 vaccine remains an urgent global health need. Identifying and characterizing broadly neutralizing antibodies (bnAbs) is essential to informing the design of vaccine antigens that could elicit such antibodies in vivo (2-4). A major challenge to eliciting bnAbs is the high sequence variability of the viral glycoprotein Env; accordingly, significant efforts have been made to develop immunogens to focus the antibody response toward a handful of highly conserved regions that correspond to bnAb epitopes (5-8). In contrast to these bnAb epitopes on the native conformation of Env, one highly conserved region of HIV-1 gp41, the N-heptad repeat (NHR), is only transiently exposed during viral entry. Upon binding cellular receptors, Env undergoes substantial conformational changes to form the pre-hairpin intermediate (PHI), in which the NHR and C-heptad repeat (CHR) regions are exposed before the cellular and viral membranes come together for membrane fusion (9-11).

Due to its high sequence conservation ( $93 \%)$ (12) and critical role in viral entry (9), the NHR is a promising target for blocking HIV-1 infection. Several inhibitors of the NHR have been identified, most notably the FDA-approved fusion inhibitor enfuvirtide (13-15), validating the NHR as a therapeutic target in humans. In addition, cyclic D-peptides that bind the NHR disrupt the fusion process and inhibit HIV-1 infection $(16,17)$. Of relevance for vaccine applications, several characterized monoclonal antibodies (mAbs) target the NHR (18-20). The first of these mAbs was D5 (18), which was isolated from a human B cell-derived phage display library using two synthetic mimetics of the gp41 PHI: 5-Helix (21) and IZN36 (22). D5 exhibits weak-but broad — neutralizing potency against laboratory-adapted and primary clinical isolates of HIV-1 by binding a conserved hydrophobic pocket of the NHR and preventing the fusion of the viral and 
cellular membranes (18). X-ray crystallography revealed that complementarity-determining region (CDR) loops in the antibody variable regions of both the heavy and light chains (VH and VL, respectively) contribute to the binding of D5 to the NHR (23). Informed by this insight, Montgomery et al. (24) sought to increase the neutralization potency of D5 by randomizing residues in five of the six CDRs (VH CDR 1, 2, 3 and VL CDR 1 and 3). Four D5 IgG variants, each with only one CDR mutated, had slightly increased neutralization potency (24).

Here we hypothesized that combining multiple CDR mutations from these D5 variants would create a more potent mAb against HIV-1. To test this hypothesis, we evaluated a panel of 16 variants: wild-type D5, four previously described CDR variants (24), and 11 recombined CDR variants (Figure 1). The 11 recombined CDR variants are composed of combinations of the CDR sequences found in the four enhanced D5 variants. We determined that D5_AR, the most potent recombined variant, has increased neutralization efficacy in all tier-1 and tier-2 HIV-1 viruses tested compared to D5. As recently reported for D5 (25), and as previously characterized for membrane proximal external region (MPER) mAbs $(26,27)$, the neutralization potency of D5_AR was enhanced at least 1,000-fold in target TZM-bl cells expressing the high-affinity immunoglobulin receptor Fc $\gamma \mathrm{RI}$ (TZM-bl/Fc $\gamma \mathrm{RI}$ cells). Although not expressed on CD4+ T cells, Fc $\gamma \mathrm{RI}$ is expressed on macrophages and dendritic cells (28), which are thought to be important in the early sexual transmission of HIV-1 at mucosal surfaces (29-36). D5_AR demonstrates cross-clade tier-2 HIV-1 neutralizing activity and extremely potent activity when measured in cells expressing FcyRI, suggesting that the PHI may be a promising vaccine target for eliciting neutralizing antibodies with broad heterologous neutralization potency. 


\section{$\underline{\text { Results }}$}

\section{D5_AR, a recombined CDR mutant of D5, has enhanced neutralization potency against}

\section{HIV-1 in vitro}

To assess the impact on neutralization after the introduction of multiple mutated CDRs, we recombinantly expressed and purified wild-type D5 IgG and 15 D5 IgG variants (Figure 1). The variants were designated D5_HXXX_LX (Figure 1C), with each X replaced by either 0 (representing the wild-type sequence) or 1 (representing the mutated CDR sequence) in the heavy (CDR 1, 2, and 3) or light (CDR3) chain (Figure 1A), reported by Montgomery et al. (24). These four CDRs form critical points of contact at the D5 epitope of the NHR (Figure 1B). The full amino acid sequences for the heavy and light chain variable regions of each mutant are provided in Supplemental Figures 1 and 2. Using single-round infectivity assays in TZM-bl cells, each D5 IgG variant was screened for neutralization potency against lentivirus pseudotyped with HIV-1 HXB2 Env (37-41). Neutralization potency was reported as the 50\% inhibitory dose (ID 50 ). We confirmed that the four single-CDR mutants previously described by Montgomery et al. (24) (D5_H100_L0, D5_H010_L0, D5_H001_L0, and D5_H000_L1) displayed enhanced neutralization versus the parent D5 (Supplemental Table 1).

Next, we screened 11 additional D5 variants with lentivirus pseudotyped with HIV-1 HXB2 Env for neutralization potency using a single-round infectivity assay. Several recombinant D5 variants had little effect or even diminished the neutralization potency compared to D5 (Table 1). Nevertheless, we identified six D5 variants that modestly enhanced $(>2.0$-fold $)$ the neutralization potency of D5 (Table 1). Among these, D5_H011_L0, in which both CDR2 and CDR3 of the heavy chain are mutated, demonstrated the greatest enhancement (4-fold) in ID $_{50}$ (Table 1). We renamed this most potent D5 variant D5_AR for further characterization. 
Our initial neutralization screen utilized antibody purified via Protein A affinity chromatography (Materials and Methods). During subsequent antibody purification, we removed aggregates through an additional size exclusion chromatography (SEC) step; comparison of neutralization potencies revealed that the presence of aggregates reduced the neutralization potencies of D5 and D5_AR (Supplementary Information, Supplemental Figure 3). Experiments in Table 1 and Supplemental Table 1 were the only experiments reported here that used non-SEC-purified antibody preparations, which accounts for the difference in $\mathrm{ID}_{50}$ values for HXB2 reported in Table 1 and Figure 3.

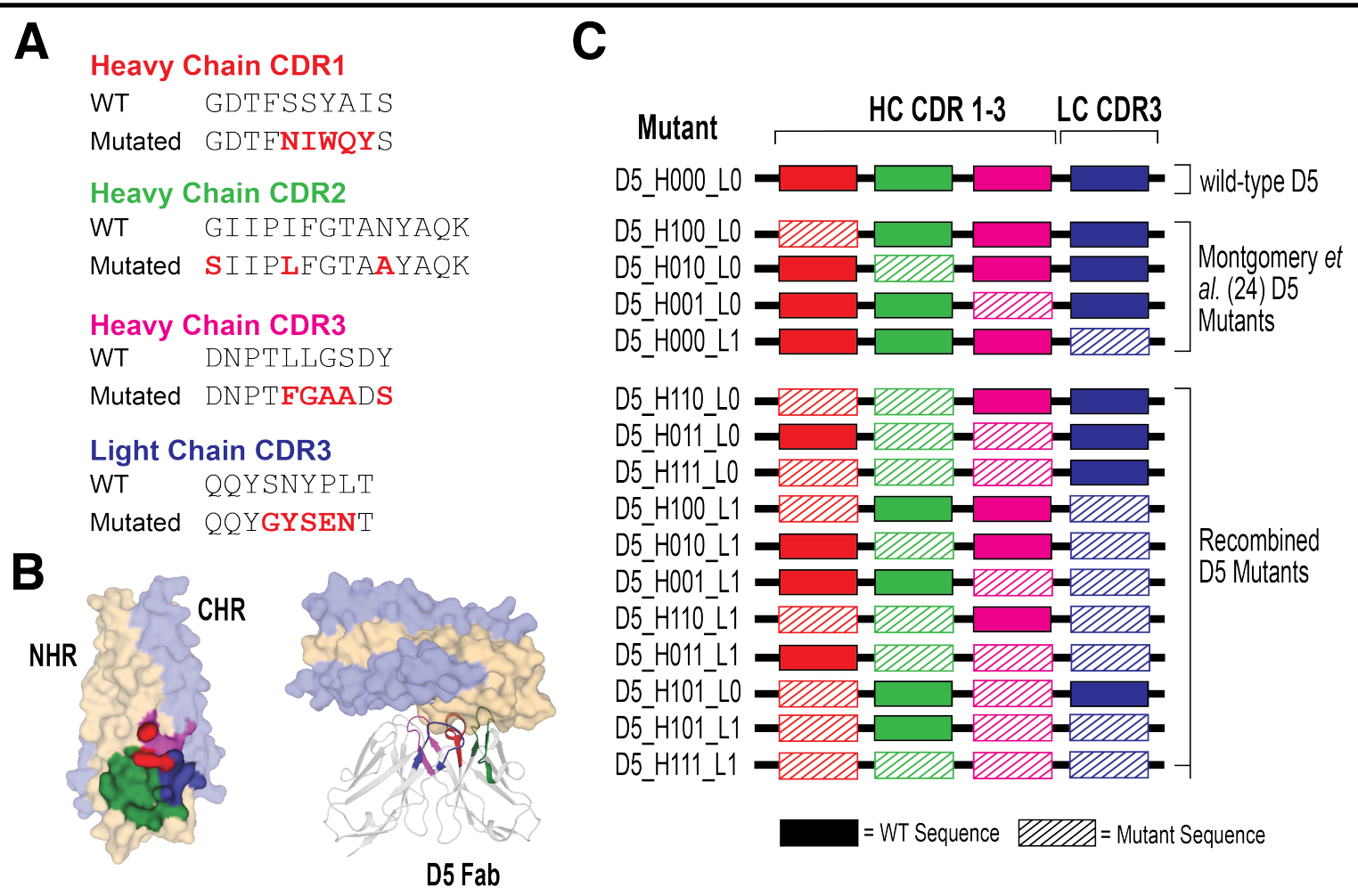

Figure 1: Recombination of known beneficial CDR sequences to engineer novel D5 variants.

(A) Mutated CDR sequences of four highlighted D5 variants reported by Montgomery et al. (24) aligned with the wild-type (WT) sequence. These mutated CDR sequences were recombined to engineer the 11 recombined variants. (B) Left: paratope map of the binding sites for D5 Fab with its antigen, 5-Helix. NHR, yellow; CHR, light blue. Areas of contact with the D5 CDR loops are represented as: VH CDR1 (red), VH CDR2 (green), VH CDR3 (magenta), and VL CDR3 (blue). Right: X-ray crystal structure of D5 in complex with 5-Helix (PDB: 2CMR) (23). (C) Schematic of D5 variants engineered and tested. The identity of each of the four CDR loops are represented by 0 (WT) or 1 (mutant). 
neutralization for D5 using antibody preparations free of aggregates. Notably, in agreement with the initial report (18) and in contrast to the previous reports $(20,23,24,42)$, we found that D5 as an IgG, Fab, and scFv (all SEC-purified) did not exhibit a size-dependent pattern of neutralization (Figure 2A). Additionally, we detected comparable neutralization potency for D5_AR as an scFv, Fab, and IgG (Figure 2B). These results demonstrate that neither D5 nor D5_AR are impacted by steric hindrance and suggest the presence of protein aggregates could explain previous reports of size-dependent neutralization for D5 scFv, Fab, and IgG.
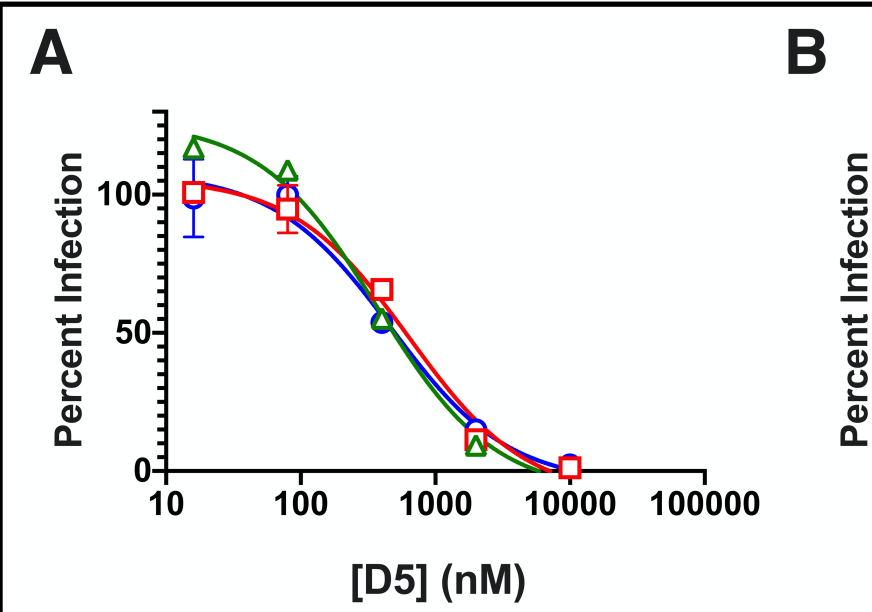

Figure 2: D5 and D5_AR neutralize HIV-1 in vitro in a size-independent manner. $\mathrm{scFv}, \mathrm{Fab}$, and IgG constructs of (A) D5 and (B) D5_AR are similarly effective in vitro at neutralizing lentivirus pseudotyped with HIV-1 HXB2. Data points and error bars are the mean percent infection and standard error of the mean, respectively $(n=2)$. Antibody construct images used in this figure were generated with BioRender.

\section{D5_AR exhibits more potent cross-clade tier-2 neutralization of HIV-1 viruses than D5}

We next investigated the potency of D5_AR IgG in neutralizing a diverse panel of 19 tier-1 and tier-2 pseudotyped viruses across eight viral clades (A, AC, B, C, G, CRF01, CRF02, and CRF07) (40, 45-60). Ten of these strains originated from a 12-virus panel designed to capture the sequence diversity of the HIV-1 epidemic globally (40). Tier 1A and tier 1B contain viruses that are most sensitive to neutralization by antibodies, whereas tier-2 viruses have modest sensitivity to neutralizing antibodies (52). D5_AR IgG neutralized virus more effectively than D5 IgG across 


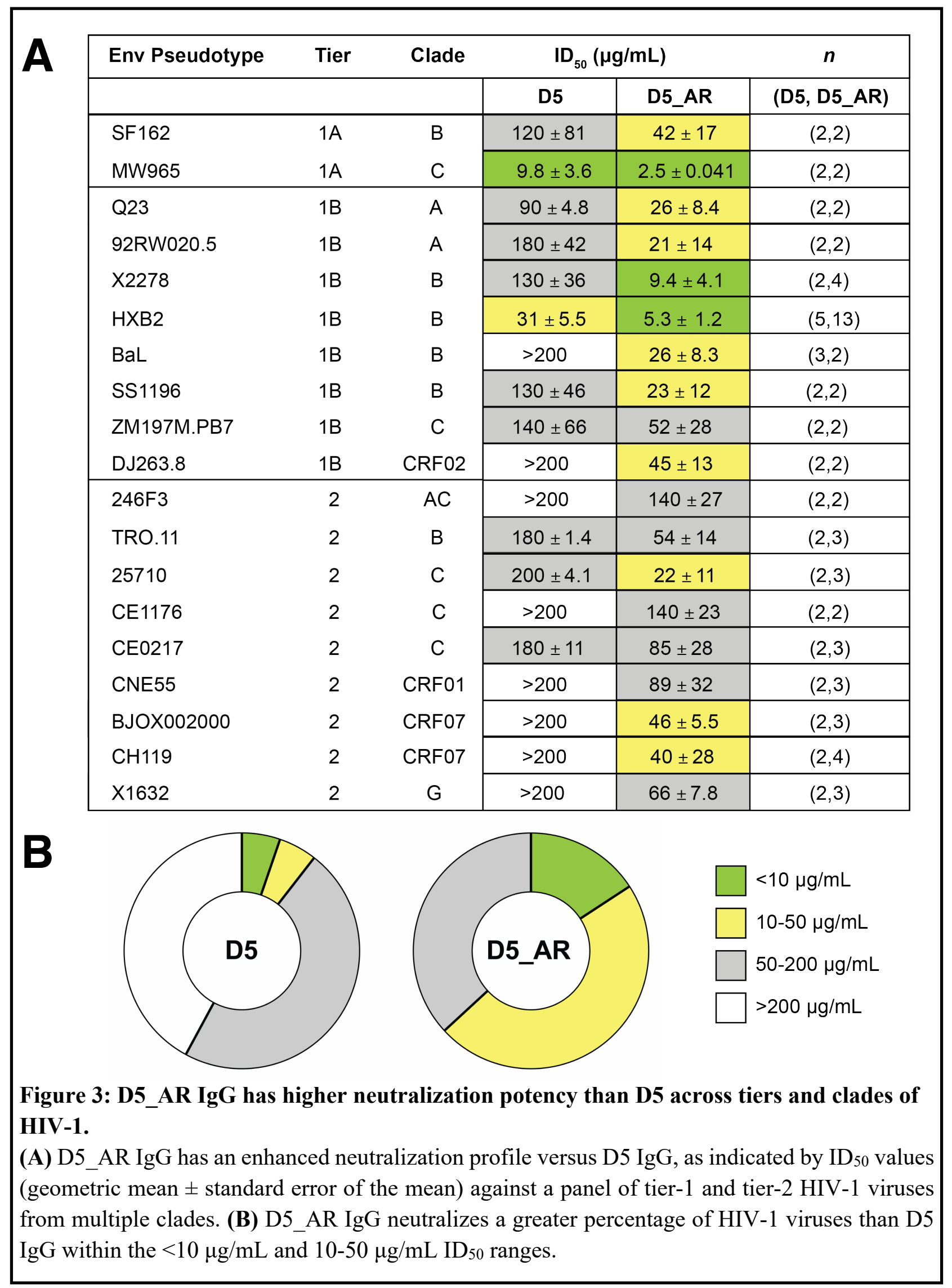


all tiers and clades (Figure 3A). Notably, D5_AR neutralizes more viruses with an $\mathrm{ID}_{50}$ of $<50$ $\mu \mathrm{g} / \mathrm{mL}(63 \%)$ than D5 (11\%) (Figure 3B).

\section{D5_AR neutralization potency is enhanced $>\mathbf{1 , 0 0 0 - f o l d ~ i n ~ F c y R I - e x p r e s s i n g ~ c e l l s ~}$}

Recently, we reported the neutralization potency of D5 IgG to be greatly increased in TZM-bl cells expressing the cell-surface receptor Fc $\gamma R I$ (TZM-bl/Fc $\gamma$ RI cells) (25). Fc $\gamma$ RI is the only known high-affinity IgG receptor in humans, capable of binding monomeric IgG (61). To determine whether D5_AR IgG is similarly potentiated, we tested its neutralization of an additional panel of tier-2 HIV-1 viruses and SHIV challenge viruses in TZM-bl/Fc $\gamma$ RI cells (Figure 4). Indeed, neutralization by D5_AR IgG was potentiated $\sim 1,000$-fold in TZM-bl/FcyRI cells versus TZM-bl cells (Figure 4A and 4B). In the presence of Fc $\gamma$ RI, D5_AR had potent neutralization activity against a panel of tier-2 HIV-1 viruses, with ID $_{50}$ values $<0.1 \mu \mathrm{g} / \mathrm{mL}$ (Figure 4C and 4D). Consistent with an Fc-dependent mechanism, the Fab form of D5_AR did not exhibit potentiation (Figure 5A). This observed potentiation was specific to Fc $\gamma \mathrm{RI}$ : enhanced neutralization was minimal or not observed in cell lines expressing other Fc receptors (Fc $\gamma$ RIIa, Fc $\gamma$ RIIb, and Fc $\gamma$ RIIIa; Figure 5B). It is noteworthy that the ID 50 values of D5_AR IgG in TZM-bl cells were approximately linearly related to the ID 50 values in TZM-bl/Fc $\gamma$ RI cells (Figure 6). 


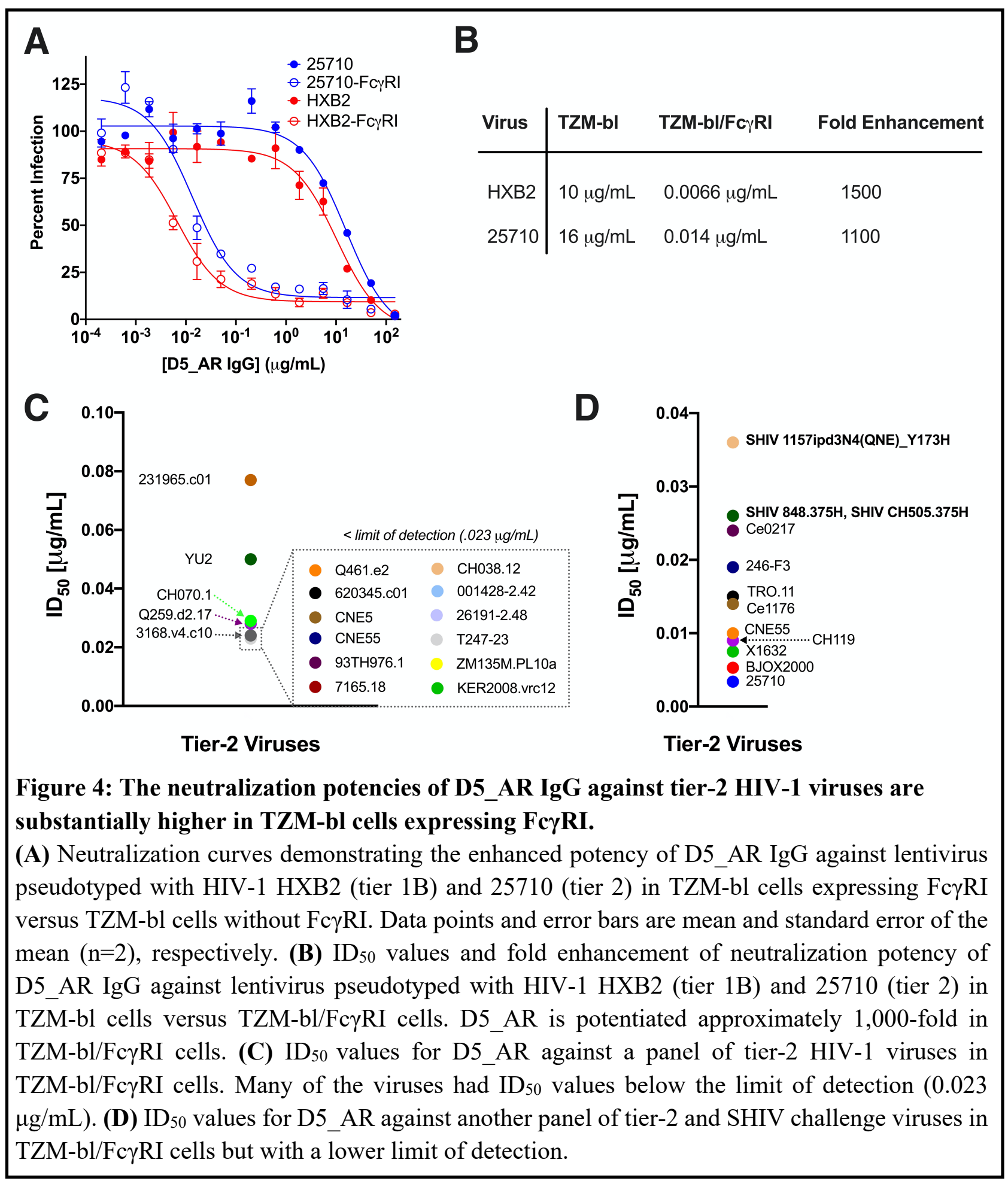



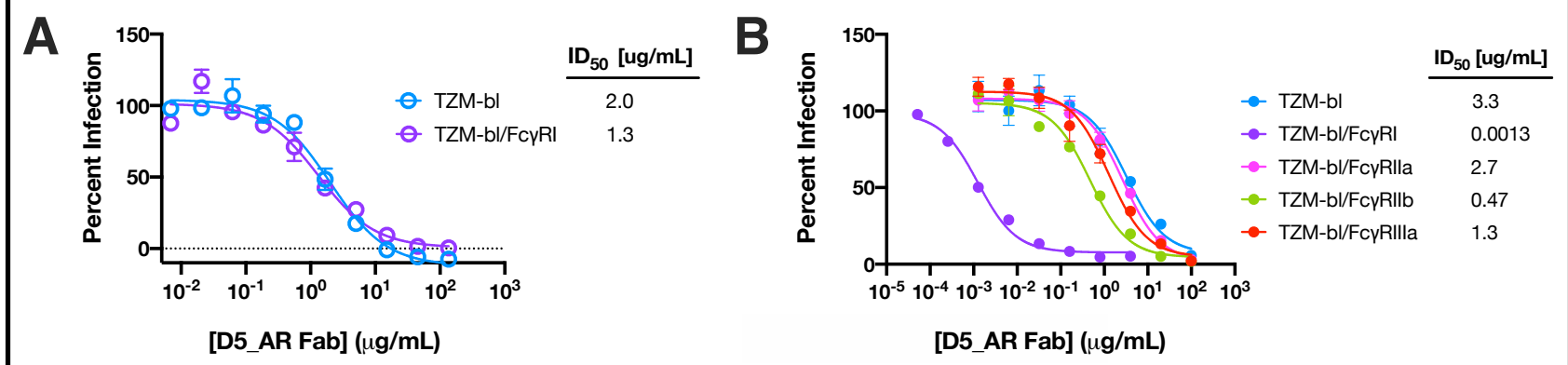

Figure 5: D5_AR is not potentiated as a Fab and shows minimal or no potentiation in the presence of other $\mathrm{Fc}$ receptors.

(A) Neutralization curves for D5_AR Fab against lentivirus pseudotyped with HIV-1 HXB2 show no neutralization enhancement between TZM-bl cells and TZM-bl/Fc $\gamma$ RI cells. Data points and error bars are the mean and standard error of the mean $(n=2)$, respectively. (B) The degree of observed neutralization enhancement is FcyRI-specific, as demonstrated by the neutralization potency of D5 AR IgG against lentivirus pseudotyped with HIV-1 HXB2 in TZM-bl cells expressing various Fc receptors. Data points and error bars are the mean and standard error of the mean $(n=3)$, respectively.

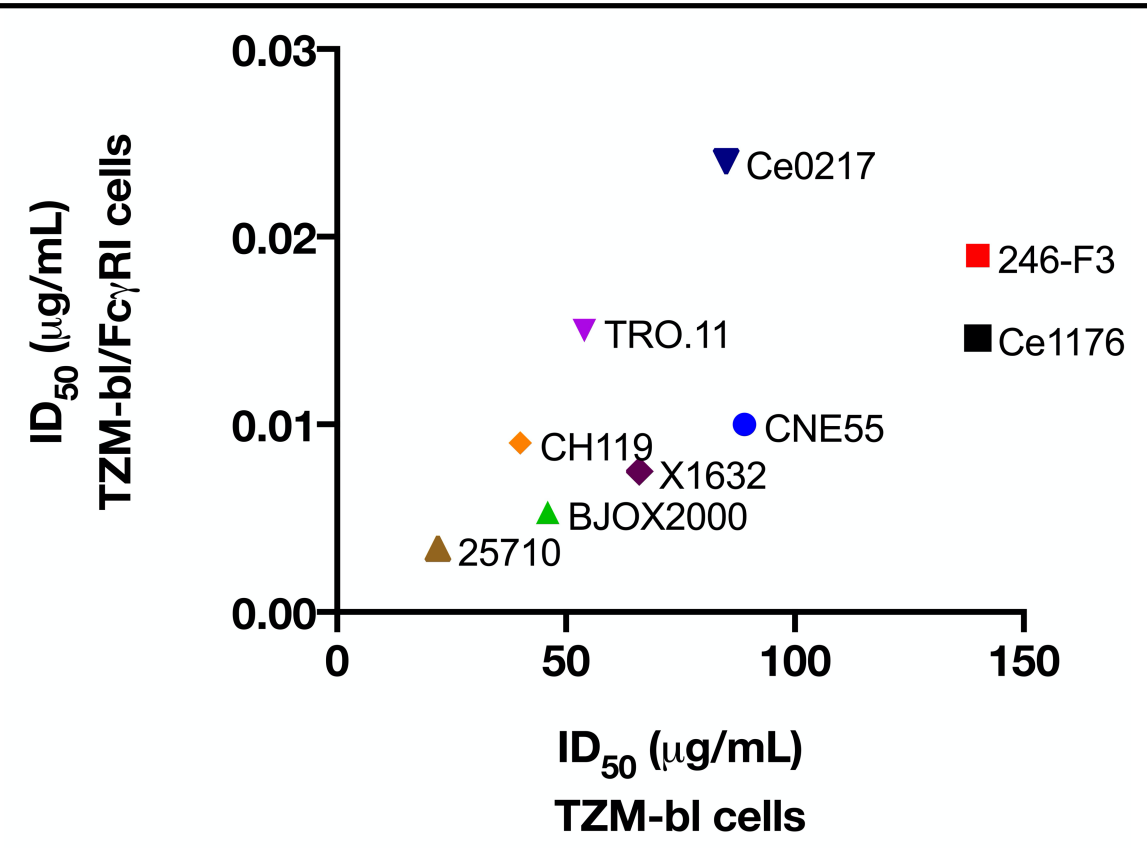

Figure 6: Comparison of HIV-1 neutralizing activity of D5 AR IgG in TZM-bl versus TZM-bl/Fc $\gamma$ RI cells.

The ID 50 values of D5 AR IgG in TZM-bl and TZM-bl/Fc $\gamma$ RI cells are approximately linearly related in a panel of tier-2 HIV-1 viruses from multiple clades. ID $_{50}$ values represented in this figure were reported previously in Figure 3 and 4. 


\section{$\underline{\text { Discussion }}$}

The PHI of HIV-1 is a validated drug target in humans (13-15), and antibodies that bind the NHR of gp41 that is exposed in the PHI can inhibit HIV-1 infection in vitro (18-20). The first of these NHR-binding antibodies, D5, has weak neutralization potency against tier-1 HIV-1 strains (18). Here we engineered and characterized a more potent D5 derivative, D5_AR, which exhibited enhanced neutralization of tier-1 strains and weak cross-clade neutralization of tier-2 HIV-1 viruses (Figure 3). Using ten global HIV-1 reference strains, we determined that at modest concentrations (1-50 $\mu \mathrm{g} / \mathrm{mL})$, D5_AR neutralizes the majority of tier-1 and tier-2 HIV-1 strains tested from a variety of clades (Figure 3). Taken together with the high sequence conservation of the NHR (12), these results support future vaccine design efforts to elicit neutralizing antibodies against the PHI.

Several previous reports had suggested that access to the D5 epitope was impacted by steric hindrance, as smaller antibody constructs were more potent than full-length $\operatorname{IgG}(20,23,24,42)$. We reinvestigated this issue using antibody preparations that were free of observed protein aggregates (Supplementary Information; Supplemental Figure 3). In contrast to earlier reports (20, 23, 24, 42), here we confirm (18) that D5 and D5_AR are similarly potent when tested in neutralization assays in $\mathrm{scFv}, \mathrm{Fab}$, and IgG formats (Figure 2). We hypothesize that the presence of higher-order protein aggregates (that can be removed by SEC) may explain the previous reports of size-dependent neutralization by D5. Given these findings for D5 and D5_AR, we conclude that steric hindrance is not an obstacle for at least some anti-PHI antibodies.

Previous work on antibodies targeting another epitope of gp41, the MPER, found that neutralization activity was potentiated as much as 5,000-fold in cells expressing Fc $\gamma \mathrm{RI}$, an integral membrane protein that interacts with the Fc portion of $\gamma$ immunoglobulins (26-28). Since the 
MPER is not fully exposed until after Env engages with cellular receptors $(62,63)$, these results suggest that by binding the Fc region of MPER mAbs, Fc $\gamma$ RI provides a local concentration advantage at the cell surface that enhances neutralization $(26,27)$. Because the PHI, like the MPER, is fully exposed only during viral membrane fusion, we previously investigated the effect of Fc $\gamma \mathrm{RI}$ on D5 and found neutralization by this anti-PHI mAb is also enhanced $~ 5,000$-fold (25). Like D5, D5_AR IgG displayed 1,000-fold enhancement in neutralization potency in TZM-b1/Fc $\gamma R$ I cells (Figure 4A and 4B). Notably, this enhancement makes D5_AR IgG an extremely potent neutralizing antibody of tier-2 HIV-1 viruses in the TZM-bl/Fc $\gamma$ RI cell line, with ID 50 values below $0.1 \mu \mathrm{g} / \mathrm{mL}$ (Figure 4C and 4D).

TZM-bl/Fc $\gamma$ RI cells enable sensitive detection of neutralization activity from anti-NHR antibodies and could be used, in conjunction with TZM-bl cells, to monitor progress toward eliciting neutralizing antisera. We hypothesize that neutralizing activity detected by TZM-bl/Fc $\gamma \mathrm{RI}$ cells could be used as an indicator of low-affinity antibody precursors in serum that have the potential to mature to high-affinity neutralizing activity independent of Fc $\gamma$ RI. This hypothesis is supported by our findings that the neutralizing activity of D5_AR in Fc $\gamma$ RI-expressing cells were approximately linearly related to the neutralizing activity of D5_AR in cells without Fc $\gamma$ RI (Figure $6)$.

Although not normally expressed on CD4+ T cells, Fc $\gamma \mathrm{RI}$ receptors are expressed on some cells at mucosal surfaces where sexual HIV-1 transmission occurs, such as macrophages and dendritic cells (28). Mucosal macrophages and dendritic cells can be productively infected by HIV-1 (29-32) and can then mediate viral transmission to CD4+ T cells (33-36). Importantly, studies of intravaginal inoculation of simian immunodeficiency virus (SIV) of non-human primates demonstrated that intraepithelial and submucosal dendritic cells are infected in the 
earliest stages (18-48 hours) of SIV infection (64-67). More recent work has shown that at 48 hours post-inoculation, $25 \%$ of infected cells are dendritic cells and macrophages, with the remainder comprising CD4+ T cells, primarily of the Th17 type $(68,69)$. Thus, it is plausible that inhibiting HIV-1 infection of these Fc $\gamma$ RI-expressing cells at the mucosal surfaces could decrease the likelihood of sexual HIV-1 transmission.

Indeed, in a vaginal challenge with SHIV in rhesus macaques, an MPER mAb (2F5) afforded dose-dependent protection when administered as an $\mathrm{IgG}$, but not when administered in its Fab form (70), suggesting an Fc-dependent mechanism of protection in vivo. Previous studies have also demonstrated that MPER mAbs are much more protective against SHIV challenge than when measured in vitro, compared to other bnAbs (71-73). Considered alongside these previous findings, the extremely potent activity of D5_AR observed here against HIV-1 infection of FcyRI-expressing cells (Figure 4) motivates future efforts to investigate the ability of passively transferred anti-PHI antibodies to protect against sexual HIV-1 transmission in vivo.

Taken together, the findings presented here provide evidence that the NHR of the PHI is a promising target for future HIV-1 vaccine development, and pave the way for future studies of the in vivo significance of Fc $\gamma$ RI-mediated potentiation of anti-PHI antibodies. 


\section{Materials and Methods}

\section{Mammalian expression of D5 constructs}

The variable heavy $(\mathrm{VH})$ chain regions of the D5 variants were ordered as gene fragments from Twist Biosciences (Supplemental Figure 1A). Gene fragments were resuspended to $10 \mathrm{ng} / \mu \mathrm{L}$ in $\mathrm{H}_{2} \mathrm{O}$ and PCR amplified using the following two primers: (HC_forward) 5'-ACCGGTGTACATTCCCAGGTTCAAC-3' and (HC_reverse) 5'-GCCCTTGGTCGACGCGCTTGATACG-3'. The mutated variable light (VL) chain region, with only the third CDR mutated according to Montgomery et al. (24), was ordered as a G-block gene fragment from Integrated DNA Technologies and PCR amplified using the following two primers: (LC_forward) 5'-ACCGGTGTACATTCAGATATTCAAATGAC-3' and (LC_reverse) 5'- TGCAGCCACCGTACGTTTG-3'. Purified VH and VL fragments were cloned into linearized pCMVR with either the human IgG heavy or kappa light constant regions, respectively $(74,75)$. The primers for linearizing the pCMVR IgG heavy chain plasmid were: (HC_lin_forward) 5'-GCGTCGACCAAGGGCCCATCGGTCTTC-3' and (HC_lin_reverse) 5'- GGAATGTACACCGGTTGCAGTTGCTACTAGAAAAAG -3'. The primers for linearizing the pCMVR IgG kappa light chain plasmid were: (LC_lin_forward) 5'-CGTACGGTGGCTGCACCATCTGTCTTCATCTTC-3' and (LC_lin_reverse) 5'-TGAATGTACACCGGTtGCAGTtGCTACTAGAAAAAGGATGATA-3'. The D5 VH and VL segments were cloned into the linearized pCMVR backbones with 5X In-Fusion HD Enzyme Premix (Takara Bio). Plasmids were transformed into Stellar Competent Cells (Takara Bio) and transformed cells were grown at $37^{\circ} \mathrm{C}$. Colonies were sequence confirmed and then maxi-prepped $\left(\right.$ NucleoBond $^{\circledR}$ Xtra Maxi, Macherey-Nagel). Plasmids were sterile filtered using a 0.22- $\mu \mathrm{m}$ syringe filter and stored at $-20^{\circ} \mathrm{C}$. 
D5 IgG variants used for neutralization assays were expressed in Expi293FTM cells (Thermo Fisher Scientific) using FectoPRO® (Polyplus). VH and VL plasmids were co-transfected at a 1:2 ratio, respectively; cells were transfected at $3 \times 10^{6}$ cells $/ \mathrm{mL}$. Cell cultures were incubated at $37{ }^{\circ} \mathrm{C}$ and $8 \% \mathrm{CO}_{2}$ with shaking at $120 \mathrm{rpm}$. Cells were harvested 3 days post transfection by spinning at $300 \times \mathrm{g}$ for $5 \mathrm{~min}$ and then filtered through a $0.22-\mu \mathrm{m}$ filter. $\mathrm{IgG}$ supernatants were diluted 1:1 with $1 \mathrm{X}$ phosphate-buffered saline (PBS) and batch-bound to Pierce $^{\mathrm{TM}}$ Protein A agarose (Thermo Fisher Scientific) overnight at $4{ }^{\circ} \mathrm{C}$. The supernatant/resin slurry was added to a column and the resin was washed with $1 \mathrm{X}$ PBS and eluted with $100 \mathrm{mM}$ glycine [pH 2.8] into 1/10 volume of $1 \mathrm{M}$ Tris [pH 8.0].

D5 and D5_AR Fab used for neutralization assays were also produced in Expi293FTM cells. D5 and D5_AR Fab VH regions were cloned into a pCMVR heavy chain linearized backbone with a portion ( $\mathrm{CH} 2$ and $\mathrm{CH} 3$ domains) of the constant region removed. Fab VH and VL plasmids were co-transfected and harvested with the protocol for IgG described above. Fab supernatants were diluted 1:1 with $50 \mathrm{mM}$ sodium acetate $[\mathrm{pH} 5.0]$, batch-bound to Pierce ${ }^{\mathrm{TM}}$ Protein $\mathrm{G}$ Agarose (Thermo Fisher Scientific) overnight at $4{ }^{\circ} \mathrm{C}$, washed with $50 \mathrm{mM}$ sodium acetate [pH 5.0], and eluted with $100 \mathrm{mM}$ glycine [pH 2.8] into 1/10 volume of $1 \mathrm{M}$ Tris [pH 8.0].

D5 and D5_AR scFv constructs used for neutralization assays were expressed in Expi293FTM cells. The VH and VL regions were linked via a human muscle aldolase sequence (76), tagged with a His6-tag, and cloned into a linearized pCMVR vector (Supplemental Figure 2). The $\mathrm{scFv}$ plasmid was transfected and harvested with the same protocol as IgG and Fab. ScFv supernatants were diluted 1:1 with $10 \mathrm{mM}$ imidazole in $1 \mathrm{X}$ PBS, batch-bound to Ni-NTA agarose (Thermo Fisher Scientific) overnight at $4{ }^{\circ} \mathrm{C}$, washed with $10 \mathrm{mM}$ imidazole in $1 \mathrm{X}$ PBS, and eluted with $250 \mathrm{mM}$ imidazole in $1 \mathrm{X}$ PBS. 


\section{Purification and storage of D5 constructs}

For the initial screening in neutralization assays (Table 1 and Supplemental Table 1), there was no purification following elution from Protein A affinity purification. Elutions were buffer exchanged and spin concentrated using $1 \mathrm{X}$ PBS and Amicon ${ }^{\circledR}$ Ultra-15 $10 \mathrm{kD} 15 \mathrm{~mL}$ spin concentrators (Millipore).

For all other neutralization assays, elutions were further purified after affinity purification on an AKTA $^{\text {TM }}$ using a GE Superdex 200 Increase 10/300 GL column (GE HealthCare) in 1X PBS. After size exclusion chromatography, samples were spin concentrated using Amicon® Ultra-15 $10 \mathrm{kD} 15 \mathrm{~mL}$ spin concentrators.

$\mathrm{Fab}$ and scFv constructs were eluted from affinity purification and then purified further via size exclusion chromatography using the Superdex 200 Increase 10/300 GL column (GE HealthCare) and 1X PBS. Samples were spin concentrated as described above.

For all samples, regardless of the purification procedure, concentrated elution samples were syringe filtered using a $0.22-\mu \mathrm{m}$ filter and stored at $4{ }^{\circ} \mathrm{C}$ prior to use.

\section{Transfection to produce HIV-1 pseudotyped lentiviruses}

HEK293T cells were transiently co-transfected with a backbone plasmid as well as a HIV-1 Env plasmid for HIV-1 pseudotyped lentivirus production using the calcium phosphate transfection protocol previously described (77-79). HEK293T cells were passaged in T75 flasks and incubated at $37{ }^{\circ} \mathrm{C}$ at $5 \% \mathrm{CO}_{2}$. The growth medium used for passaging and transfections was Corning® DMEM (Dulbecco’s Modified Eagle Medium with 4.5 g/L glucose, L-glutamine, and sodium pyruvate) with $10 \%$ fetal bovine serum, $1 \%$ penicillin streptomycin (Corning), and $1 \%$ L-glutamine (Corning). 
The backbone plasmid psg3 $\Delta$ Env was obtained through the NIH AIDS Reagent Program, Division of AIDS, NIAID, NIH from Drs. John C. Kappes and Xiaoyun Wu: HIV-1 SG3 $\Delta$ Env Non-infectious Molecular Clone (Cat\#11051) $(80,81)$. The psg3 $\Delta$ Env plasmid was propagated in MAX Efficiency ${ }^{\circledR}$ Stbl2 ${ }^{\mathrm{TM}}$ cells grown at $30^{\circ} \mathrm{C}$ with shaking and Env plasmids were propagated in Stellar Competent Cells grown at $37^{\circ} \mathrm{C}$ with shaking. DNA was isolated using a maxi-prep kit (NucleoBond $^{\circledR}$ Xtra Maxi, Macherey-Nagel) and sequence confirmed.

In brief, $6 \times 10^{6} \mathrm{HEK} 293 \mathrm{~T}$ cells were plated in $10-\mathrm{cm}$ petri dishes in a total volume of 10 $\mathrm{mL}$ of DMEM and incubated overnight at $37{ }^{\circ} \mathrm{C}$ and $5 \% \mathrm{CO}_{2}$ without shaking. Once the cells reached $50-80 \%$ confluency, they were transfected as follows. In a Falcon tube, $20 \mu \mathrm{g}$ of psg3 $\Delta$ Env was mixed with $10 \mu \mathrm{g}$ of Env plasmid and water for a final volume of $500 \mu \mathrm{L}$. Five hundred microliters of 2X HEPES-buffered saline [pH 7] (Alfa Aesar) were added dropwise to the mixture and $100 \mu \mathrm{L} 2.5 \mathrm{M} \mathrm{CaCl}_{2}$ were added subsequently. The mixture was incubated at room temperature for $20 \mathrm{~min}$ and then added dropwise onto the cells. Next, 12-18 $\mathrm{h}$ after transfection, the medium was aspirated from the dish and replaced with $10 \mathrm{~mL}$ of fresh DMEM with additives. Virus-containing medium was harvested $48 \mathrm{~h}$ after medium swap and centrifuged at $300 \mathrm{x} g$ for 5 min; the supernatant was sterile-filtered with a $0.45-\mu \mathrm{m}$ polyvinylidene difluoride filter and stored in $1-\mathrm{mL}$ aliquots at $-80{ }^{\circ} \mathrm{C}$.

\section{Neutralization Assay}

The neutralization assay was adapted from the TZM-bl assay protocol using HIV-1 Env-pseudotyped viruses as described previously $(38,41)$. Briefly, TZM-bl cells, derived from the JC53-bl parental cell line, were used as reporter cells in this assay and were obtained through the

NIH AIDS Reagent Program (Cat\#8129) from Dr. John C. Kappes, and Dr. Xiaoyun Wu (80, 82- 
85). TZM-bl cells are adherent HeLa cells that stably express CD4 and CCR5 and constitutively express CXCR4; they have integrated $\beta$-galactosidase and firefly luciferase reporter genes under the control of the HIV-1 LTR promoter. TZM-bl cells transduced to stably express Fc $\gamma$ RI $(26,27)$, were also used in these neutralization assays. TZM-bl cells were passaged in T25 flasks and incubated at $37{ }^{\circ} \mathrm{C}$ at $5 \% \mathrm{CO}_{2}$ without shaking. The growth medium used for passaging and neutralization assays was Corning ${ }^{\circledR}$ DMEM with $10 \%$ fetal bovine serum, 1\% penicillin streptomycin (Corning), and 1\% L-glutamine (Corning).

In brief, $5 \times 10^{3}$ TZM-bl cells were plated in the internal 60 wells of white-walled, clear-bottom, 96-well plates and incubated overnight at $37{ }^{\circ} \mathrm{C}, 5 \% \mathrm{CO}_{2}$ without shaking. All outside wells were filled with $200 \mu \mathrm{L}$ PBS to minimize evaporation. On the next day, the medium was aspirated without disturbing the cells and replaced with a final mixture composed of $1 / 4$ volume DMEM, $1 / 2$ volume HIV-1 pseudotyped lentivirus, $1 / 2$ volume D5 antibody at varying concentrations, and DEAE dextran $(10 \mu \mathrm{g} / \mathrm{mL})$. Forty-eight hours after infection, all medium was aspirated off the wells, cells were lysed and either luciferase activity was determined using BriteLite Plus Reagent (Perkin Elmer) or $\beta$-galactosidase activity was determined using Tropix Gal-Screen $^{\text {TM }}$ (Applied Biosystems) and Buffer A (Applied Biosystems). $\beta$-galactosidase readout was used for neutralizations show in Table 1, Figures 2 and 3. Luciferase readout was used for neutralizations shown in Figures 4 and 5.

Relative luminescent unit (RLU) values were quantified using a Synergy ${ }^{\text {TM }}$ HTX Multi-Mode Reader (BioTek®), normalized against cells-only reference wells, and averaged for technical replicates on the plate. Percent infectivity and propagated error values (Statistics and Data Analysis) were entered into GraphPad Prism 8. Neutralization titers are reported as the antibody concentration at which RLU were reduced by $50 \%$ compared to RLU in virus control 
wells after subtraction of background RLU in cell control wells. ID ${ }_{50}$ was calculated using the [inhibitor] vs. response (three parameters) dose-response curve fit in GraphPad Prism 8. This assay was conducted in compliance with good clinical laboratory procedures (86), including participation in a formal TZM-bl assay proficiency program for GCLP-compliant laboratories (37).

\section{Statistics and Data Analysis}

Percent infectivity for the neutralization assays was calculated as follows: $\left(\frac{\text { Sample } R L U-\text { Cells Only } R L U}{\text { Virus Only } R L U-\text { Cells Only } R L U}\right) \times 100$. Propagated error for the percent infectivity was calculated using the following formula: $(\%$ Infection $) \times \sqrt{\left(\frac{S T D \text { of Sample } R L U}{\text { AVG of Sample RLU }}\right)^{2}+\left(\frac{\text { STD of Virus Only RLU }}{\text { AVG of Virus Only RLU }}\right)^{2}}$. The $\mathrm{ID}_{50}$ values in Table 1 and Figure 3 represent the geometric mean of the biological replicates for the tested antibodies with the standard error of the mean reported. Fold difference in ID $_{50}$ was calculated for each experiment by dividing the $\mathrm{D} 5 \mathrm{ID}_{50}$ by the $\mathrm{D} 5$ variant $\mathrm{ID}_{50}$. Because fold difference was calculated for each experiment, the reported fold differences in Table 1 and Figure 3 are the geometric mean and the standard error of the mean from all replicates. 


\section{$\underline{\text { Author Contributions }}$}

AAR, MVFI, CLB, and PSK conceived the experiments. AAR performed protein purification, antibody characterization, and neutralization assays. MVFI and BNB performed protein purification and neutralization assays. Additional neutralization assays were also conducted under the supervision of CCL and DCM. All authors contributed to revising the manuscript.

\section{$\underline{\text { Acknowledgments }}$}

We thank members of the Kim Lab for helpful discussions and Drs. A. E. Powell, S. Tang, and D. $\mathrm{Xu}$ for critical reading of this manuscript. This research was supported by the National Institute of General Medical Sciences of the National Institutes of Health under award numbers T32GM007276 (BNB) and 5T32GM007365 (MVFI), the NSF GRFP (BNB), NIH/NIAID contract HHSN272201800004C (CCL), the Bill and Melinda Gates Foundation award OPP1113682 (PSK), the Virginia and D. K. Ludwig Fund for Cancer Research (PSK), and the Chan Zuckerberg Biohub (PSK). 


\section{$\underline{\text { References }}$}

1. WHO. 2020. HIV/AIDS Fact Sheet. https://www.who.int/news-room/fact-sheets/detail/hiv-aids Accessed $[9 / 14 / 2020]$

2. Burton DR, Desrosiers RC, Doms RW, Koff WC, Kwong PD, Moore JP, Nabel GJ, Sodroski J, Wilson IA, Wyatt RT. 2004. HIV vaccine design and the neutralizing antibody problem. Nat Immunol 5:233-236.

3. Stamatatos L, Morris L, Burton DR, Mascola JR. 2009. Neutralizing antibodies generated during natural hiv-1 infection: Good news for an hiv-1 vaccine? Nat Med 15:866-870.

4. Ahmed Y, Tian M, Gao Y. 2017. Development of an anti-HIV vaccine eliciting broadly neutralizing antibodies. AIDS Res Ther 14, 50.

5. Sanders RW, Van Gils MJ, Derking R, Sok D, Ketas TJ, Burger JA, Ozorowski G, Cupo A, Simonich C, Goo L, Arendt H, Kim HJ, Lee JH, Pugach P, Williams M, Debnath G, Moldt B, Van Breemen MJ, Isik G, Medina-Ramírez M, Back JW, Koff WC, Julien JP, Rakasz EG, Seaman MS, Guttman M, Lee KK, Klasse PJ, LaBranche C, Schief WR, Wilson IA, Overbaugh J, Burton DR, Ward AB, Montefiori DC, Dean H, Moore JP. 2015. HIV-1 neutralizing antibodies induced by native-like envelope trimers. Science 349, aac4223.

6. Georgiev IS, Gordon Joyce M, Zhou T, Kwong PD. 2013. Elicitation of HIV-1-neutralizing antibodies against the CD4-binding site. Curr Opin HIV AIDS 8:382-392.

7. Duan H, Chen X, Boyington JC, Cheng C, Zhang Y, Jafari AJ, Stephens T, Tsybovsky Y, Kalyuzhniy O, Zhao P, Menis S, Nason MC, Normandin E, Mukhamedova M, DeKosky BJ, Wells L, Schief WR, Tian M, Alt FW, Kwong PD, Mascola JR. 2018. Glycan Masking Focuses Immune Responses to the HIV-1 CD4Binding Site and Enhances Elicitation of VRC01-Class Precursor Antibodies. Immunity 49:301-311.e5.

8. Pantophlet R, Burton DR. 2006. GP120: Target for neutralizing HIV-1 antibodies. Annu Rev Immunol 24:739-769.

9. Chan DC, Kim PS. 1998. HIV-1 entry and its inhibition. Cell 93:681-684.

10. Harrison SC. 2015. Viral membrane fusion. Virology 479-480:498-507.

11. Ladinsky MS, Gnanapragasam PN, Yang Z, West AP, Kay MS, Bjorkman PJ. 2020. Electron tomography visualization of HIV-1 fusion with target cells using fusion inhibitors to trap the pre-hairpin intermediate. elife 9, e58411.

12. Los Alamos National Laboratory. HIV sequence database main page. https://www.hiv.lanl.gov/content/sequence/HIV/mainpage.html Accessed [9/14/2020]

13. Wild C, Greenwell T, Matthews T. 1993. A Synthetic Peptide from HIV-1 gp41 Is a Potent Inhibitor of Virus-Mediated Cell—Cell Fusion. AIDS Res Hum Retroviruses 9:1051-1053.

14. Kilby JM, Lalezari JP, Eron JJ, Carlson M, Cohen C, Arduino RC, Goodgame JC, Gallant JE, Volberding P, Murphy RL, Valentine F, Saag MS, Nelson EL, Sista PR, Dusek A. 2002. The safety, plasma pharmacokinetics, and antiviral activity of subcutaneous enfuvirtide (T-20), a peptide inhibitor of gp41mediated virus fusion, in HIV-infected adults. AIDS Res Hum Retroviruses 18:685-693.

15. Matthews T, Salgo M, Greenberg M, Chung J, DeMasi R, Bolognesi D. 2004. Enfuvirtide: The first therapy to inhibit the entry of HIV-1 into host CD4 lymphocytes. Nat Rev Drug Discov 3:215-225.

16. Eckert DM, Malashkevich VN, Hong LH, Carr PA, Kim PS. 1999. Inhibiting HIV-1 entry: Discovery of Dpeptide inhibitors that target the gp41 coiled-coil pocket. Cell 99:103-115.

17. Nishimura Y, Francis JN, Donau OK, Jesteadt E, Sadjadpour R, Smith AR, Seaman MS, Welch BD, Martin MA, Kay MS. 2020. Prevention and treatment of SHIVAD8 infection in rhesus macaques by a potent dpeptide HIV entry inhibitor. Proc Natl Acad Sci 117:22436-22442.

18. Miller MD, Geleziunas R, Bianchi E, Lennard S, Hrin R, Zhang H, Lu M, An Z, Ingallinella P, Finotto M, Mattu M, Finnefrock AC, Bramhill D, Cook J, Eckert DM, Hampton R, Patel M, Jarantow S, Joyce J, Ciliberto G, Cortese R, Lu P, Strohl W, Schleif W, McElhaugh M, Lane S, Lloyd C, Lowe D, Osbourn J, Vaughan T, Emini E, Barbato G, Kim PS, Hazuda DJ, Shiver JW, Pessi A. 2005. A human monoclonal antibody neutralizes diverse HIV-1 isolates by binding a critical gp41 epitope. Proc Natl Acad Sci U S A 102:14759-14764.

19. Gustchina E, Li M, Louis JM, Eric Anderson D, Lloyd J, Frisch C, Bewley CA, Gustchina A, Wlodawer A, Marius Clore G. 2010. Structural basis of HIV-1 neutralization by affinity matured fabs directed against the internal trimeric coiled-coil of gp41. PLoS Pathog 6, e1001182.

20. Sabin C, Corti D, Buzon V, Seaman MS, Hulsik DL, Hinz A, Vanzetta F, Agatic G, Silacci C, Mainetti L, Scarlatti G, Sallusto F, Weiss R, Lanzavecchia A, Weissenhorn W. 2010. Crystal structure and sizedependent neutralization properties of HK20, a human monoclonal antibody binding to the highly conserved 
21. Root MJ, Kay MS, Kim PS. 2001. Protein Design of an HIV-1 Entry Inhibitor. Science 291:884-888.

22. Eckert DM, Kim PS. 2001. Design of potent inhibitors of HIV-1 entry from the gp41 N-peptide region. Proc Natl Acad Sci U S A 98:11187-11192.

23. Luftig MA, Mattu M, Di Giovine P, Geleziunas R, Hrin R, Barbato G, Bianchi E, Miller MD, Pessi A, Carfí A. 2006. Structural basis for HIV-1 neutralization by a gp41 fusion intermediate-directed antibody. Nat Struct Mol Biol 13:740-747.

24. Montgomery DL, Wang YJ, Hrin R, Luftig M, Su B, Miller MD, Wang F, Haytko P, Huang L, Vitelli S, Condra J, Liu X, Hampton R, Carfi A, Pessi A, Bianchi E, Joyce J, Lloyd C, Geleziunas R, Bramhill D, King VM, Finnefrock AC, Strohl W, An Z. 2009. Affinity maturation and characterization of a human monoclonal antibody against HIV-1 gp41. MAbs 1:462-474.

25. Montefiori DC, Interrante MVF, Bell BN, Rubio AA, Joyce JG, Shiver JW, LaBranche CC, Kim PS. 2020. The high-affinity immunoglobulin receptor Fc $\gamma$ RI potentiates HIV-1 neutralization via antibodies against the gp41 N-heptad repeat. bioRxiv doi: 10.1101/2020.08.27.271064

26. Perez LG, Costa MR, Todd CA, Haynes BF, Montefiori DC. 2009. Utilization of Immunoglobulin G Fc Receptors by Human Immunodeficiency Virus Type 1: a Specific Role for Antibodies against the Membrane-Proximal External Region of gp41. J Virol 83:7397-7410.

27. Perez LG, Zolla-Pazner S, Montefiori DC. 2013. Antibody-Dependent, Fc $\gamma$ RI-Mediated Neutralization of HIV-1 in TZM-bl Cells Occurs Independently of Phagocytosis. J Virol 87:5287-5290.

28. van der Poel CE, Spaapen RM, van de Winkel JGJ, Leusen JHW. 2011. Functional Characteristics of the High Affinity IgG Receptor, Fc $\gamma$ RI. J Immunol 186:2699-2704.

29. Patterson S, Rae A, Hockey N, Gilmour J, Gotch F. 2001. Plasmacytoid Dendritic Cells Are Highly Susceptible to Human Immunodeficiency Virus Type 1 Infection and Release Infectious Virus. J Virol 75:6710-6713.

30. Shen R, Richter HE, Clements RH, Novak L, Huff K, Bimczok D, Sankaran-Walters S, Dandekar S, Clapham PR, Smythies LE, Smith PD. 2009. Macrophages in Vaginal but Not Intestinal Mucosa Are Monocyte-Like and Permissive to Human Immunodeficiency Virus Type 1 Infection. J Virol 83:3258-3267.

31. Kruize Z, Kootstra NA. 2019. The Role of Macrophages in HIV-1 Persistence and Pathogenesis. Front Microbiol 10, 2828.

32. Smed-Sörensen A, Loré K, Vasudevan J, Louder MK, Andersson J, Mascola JR, Spetz A-L, Koup RA. 2005. Differential Susceptibility to Human Immunodeficiency Virus Type 1 Infection of Myeloid and Plasmacytoid Dendritic Cells. J Virol 79:8861-8869.

33. Loré K, Smed-Sörensen A, Vasudevan J, Mascola JR, Koup RA. 2005. Myeloid and plasmacytoid dendritic cells transfer HIV-1 preferentially to antigen-specific CD4+ T cells. J Exp Med 201:2023-2033.

34. Groot F, Welsch S, Sattentau QJ. 2008. Efficient HIV-1 transmission from macrophages to T cells across transient virological synapses. Blood 111:4660-4663.

35. Waki K, Freed EO. 2010. Macrophages and cell-cell spread of HIV-1. Viruses 2:1603-1620.

36. Bracq L, Xie M, Benichou S, Bouchet J. 2018. Mechanisms for cell-to-cell transmission of HIV-1. Front Immunol 9, 260.

37. Todd CA, Greene KM, Yu X, Ozaki DA, Gao H, Huang Y, Wang M, Li G, Brown R, Wood B, D’Souza MP, Gilbert P, Montefiori DC, Sarzotti-Kelsoe M. 2012. Development and implementation of an international proficiency testing program for a neutralizing antibody assay for HIV-1 in TZM-bl cells. J Immunol Methods 375:57-67.

38. Sarzotti-Kelsoe M, Bailer RT, Turk E, Lin C, Bilska M, Greene KM, Gao H, Todd CA, Ozaki DA, Seaman MS, Mascola JR, Montefiori DC. 2014. Optimization and validation of the TZM-bl assay for standardized assessments of neutralizing antibodies against HIV-1. J Immunol Methods 409:131-146.

39. Mascola JR, D’Souza P, Gilbert P, Hahn BH, Haigwood NL, Morris L, Petropoulos CJ, Polonis VR, Sarzotti M, Montefiori DC. 2005. Recommendations for the Design and Use of Standard Virus Panels To Assess Neutralizing Antibody Responses Elicited by Candidate Human Immunodeficiency Virus Type 1 Vaccines. J Virol 79:10103-10107.

40. DeCamp A, Hraber P, Bailer RT, Seaman MS, Ochsenbauer C, Kappes J, Gottardo R, Edlefsen P, Self S, Tang H, Greene K, Gao H, Daniell X, Sarzotti-Kelsoe M, Gorny MK, Zolla-Pazner S, LaBranche CC, Mascola JR, Korber BT, Montefiori DC. 2014. Global Panel of HIV-1 Env Reference Strains for Standardized Assessments of Vaccine-Elicited Neutralizing Antibodies. J Virol 88:2489-2507.

41. Montefiori DC. 2009. Measuring HIV Neutralization in a Luciferase Reporter Gene Assay, p. 395-405. In HIV Protocols. Methods in Molecular Biology, Second Edition. 
42. Eckert DM, Shi Y, Kim S, Welch BD, Kang E, Poff ES, Kay MS. 2008. Characterization of the steric defense of the HIV-1 gp41 N-trimer region. Protein Sci 17:2091-2100.

43. Hamburger AE, Kim S, Welch BD, Kay MS. 2005. Steric accessibility of the HIV-1 gp41 N-trimer region. J Biol Chem 280:12567-12572.

44. Lu L, Wei M, Chen Y, Xiong W, Yu F, Qi Z, Jiang S, Pan C. 2013. F(ab')2 fragment of a gp41 NHRtrimer-induced IgM monoclonal antibody neutralizes HIV-1 infection and blocks viral fusion by targeting the conserved gp41 pocket. Microbes Infect 15:887-894.

45. Robertson D, Anderson J, Bradac J, Carr J, Foley B, Funkhouser R, Gao F, Hahn B, Kalish M, Kuiken C, Learn G, Leitner T, McCutchan F, Osmanov S, Peeters M, Pieniazek D, Salminen M, Sharp P, Wolinsky S, Korber B. 2000. HIV-1 nomenclature proposal. Science 288, 55.

46. Li M, Gao F, Mascola JR, Stamatatos L, Polonis VR, Koutsoukos M, Voss G, Goepfert P, Gilbert P, Greene KM, Bilska M, Kothe DL, Salazar-Gonzalez JF, Wei X, Decker JM, Hahn BH, Montefiori DC. 2005. Human Immunodeficiency Virus Type 1 env Clones from Acute and Early Subtype B Infections for Standardized Assessments of Vaccine-Elicited Neutralizing Antibodies. J Virol 79:10108-10125.

47. Li M, Salazar-Gonzalez JF, Derdeyn CA, Morris L, Williamson C, Robinson JE, Decker JM, Li Y, Salazar MG, Polonis VR, Mlisana K, Karim SA, Hong K, Greene KM, Bilska M, Zhou J, Allen S, Chomba E, Mulenga J, Vwalika C, Gao F, Zhang M, Korber BTM, Hunter E, Hahn BH, Montefiori DC. 2006. Genetic and Neutralization Properties of Subtype C Human Immunodeficiency Virus Type 1 Molecular env Clones from Acute and Early Heterosexually Acquired Infections in Southern Africa. J Virol 80:11776-11790.

48. Shang H, Han X, Shi X, Zuo T, Goldin M, Chen D, Han B, Sun W, Wu H, Wang X, Zhang L. 2011. Genetic and neutralization sensitivity of diverse HIV-1 env clones from chronically infected patients in China. J Biol Chem 286:14531-14541.

49. Revilla A, Delgado E, Christian EC, Dalrymple J, Vega Y, Carrera C, González-Galeano M, Ocampo A, De Castro RO, Lezaún MJ, Rodríguez R, Mariño A, Ordóñez P, Cilla G, Cisterna R, Santamaría JM, Prieto S, Rakhmanova A, Vinogradova A, Ríos M, Pérez-Álvarez L, Nájera R, Montefiori DC, Seaman MS, Thomson MM. 2011. Construction and phenotypic characterization of HIV type 1 functional envelope clones of subtypes G and F. AIDS Res Hum Retroviruses 27:889-901.

50. Kulkarni SS, Lapedes A, Tang H, Gnanakaran S, Daniels MG, Zhang M, Bhattacharya T, Li M, Polonis VR, McCutchan FE, Morris L, Ellenberger D, Butera ST, Bollinger RC, Korber BT, Paranjape RS, Montefiori DC. 2009. Highly complex neutralization determinants on a monophyletic lineage of newly transmitted subtype C HIV-1 Env clones from India Smita. Virology 385:505-520.

51. Li Y, Migueles SA, Welcher B, Svehla K, Phogat A, Louder MK, Wu X, Shaw GM, Connors M, Wyatt RT, Mascola JR. 2007. Broad HIV-1 neutralization mediated by CD4-binding site antibodies. Nat Med 13:10321034.

52. Seaman MS, Janes H, Hawkins N, Grandpre LE, Devoy C, Giri A, Coffey RT, Harris L, Wood B, Daniels MG, Bhattacharya T, Lapedes A, Polonis VR, McCutchan FE, Gilbert PB, Self SG, Korber BT, Montefiori DC, Mascola JR. 2010. Tiered Categorization of a Diverse Panel of HIV-1 Env Pseudoviruses for Assessment of Neutralizing Antibodies. J Virol 84:1439-1452.

53. Page KA, Landau NR, Littman DR. 1990. Construction and use of a human immunodeficiency virus vector for analysis of virus infectivity. J Virol 64:5270-5276.

54. Li Y, Svehla K, Mathy NL, Voss G, Mascola JR, Wyatt R. 2006. Characterization of Antibody Responses Elicited by Human Immunodeficiency Virus Type 1 Primary Isolate Trimeric and Monomeric Envelope Glycoproteins in Selected Adjuvants. J Virol 80:1414-1426.

55. Long EM, Rainwater SMJ, Lavreys L, Mandaliya K, Overbaugh J. 2002. HIV type 1 variants transmitted to women in Kenya require the CCR5 coreceptor for entry, regardless of the genetic complexity of the infecting virus. AIDS Res Hum Retroviruses 18:567-576.

56. Cheng-Mayer C, Liu R, Landau NR, Stamatatos L. 1997. Macrophage tropism of human immunodeficiency virus type 1 and utilization of the CC-CKR5 coreceptor. J Virol 71:1657-1661.

57. Stamatatos L, Lim M, Cheng-Mayer C. 2000. Generation and structural analysis of soluble oligomeric gp140 envelope proteins derived from neutralization-resistant and neutralization-susceptible primary HIV type 1 isolates. AIDS Res Hum Retroviruses 16:981-994.

58. Stamatatos L, Wiskerchen M, Cheng-Mayer C. 1998. Effect of major deletions in the V1 and V2 loops of a macrophage-tropic HIV type 1 isolate on viral envelope structure, cell entry, and replication. AIDS Res Hum Retroviruses 14:1129-1139.

59. Gao F, Morrison SG, Robertson DL, Thornton CL, Craig S, Karlsson G, Sodroski J, Morgado M, GalvaoCastro B, Von Briesen H, Beddows S, Weber J, Sharp PM, Shaw GM, Hahn BH. 1996. Molecular cloning 
and analysis of functional envelope genes from human immunodeficiency virus type 1 sequence subtypes $\mathrm{A}$ through G. J Virol 70:1651-1667.

60. Poss M, Overbaugh J. 1999. Variants from the diverse virus population identified at seroconversion of a clade A human immunodeficiency virus type 1-infected woman have distinct biological properties. J Virol 73:5255-5264.

61. Bruhns P, Iannascoli B, England P, Mancardi DA, Fernandez N, Jorieux S, Daëron M. 2009. Specificity and affinity of human Fc $\gamma$ receptors and their polymorphic variants for human IgG subclasses. Blood 113:37163725 .

62. Montero M, van Houten NE, Wang X, Scott JK. 2008. The Membrane-Proximal External Region of the Human Immunodeficiency Virus Type 1 Envelope: Dominant Site of Antibody Neutralization and Target for Vaccine Design. Microbiol Mol Biol Rev 72:54-84.

63. Gach JS, Leaman DP, Zwick MB. 2011. Targeting HIV-1 gp41 in Close Proximity to the Membrane Using Antibody and Other Molecules. Curr Top Med Chem 11:2997-3021.

64. Su B, Dispinseri S, Iannone V, Zhang T, Wu H, Carapito R, Bahram S, Scarlatti G, Moog C. 2019. Update on Fc-Mediated Antibody Functions Against HIV-1 Beyond Neutralization. Front Immunol 10, 2968.

65. Spira AI, Marx PA, Patterson BK, Mahoney J, Koup A, Wolinsky SM, Ho DD. 1996. Cellular targets of infection and route of viral dissemination after an intravaginal inoculation of simian immunodeficiency virus into rhesus macaques. J Exp Med 183:215-225.

66. Hu J, Gardner MB, Miller CJ. 2000. Simian Immunodeficiency Virus Rapidly Penetrates the Cervicovaginal Mucosa after Intravaginal Inoculation and Infects Intraepithelial Dendritic Cells. J Virol 74:6087-6095.

67. Pope M, Haase AT. 2003. Transmission, acute HIV-1 infection and the quest for strategies to prevent infection. Nat Med 9:847-852.

68. Stieh DJ, Maric D, Kelley ZL, Anderson MR, Hattaway HZ, Beilfuss BA, Rothwangl KB, Veazey RS, Hope TJ. 2014. Vaginal Challenge with an SIV-Based Dual Reporter System Reveals That Infection Can Occur throughout the Upper and Lower Female Reproductive Tract. PLoS Pathog 10, e1004440.

69. Stieh DJ, Matias E, Xu H, Fought AJ, Blanchard JL, Marx PA, Veazey RS, Hope TJ. 2016. Th17 Cells Are Preferentially Infected Very Early after Vaginal Transmission of SIV in Macaques. Cell Host Microbe 19:529-540.

70. Klein K, Veazey RS, Warrier R, Hraber P, Doyle-Meyers LA, Buffa V, Liao H-X, Haynes BF, Shaw GM, Shattock RJ. 2013. Neutralizing IgG at the Portal of Infection Mediates Protection against Vaginal Simian/Human Immunodeficiency Virus Challenge. J Virol 87:11604-11616.

71. Hessell AJ, Rakasz EG, Tehrani DM, Huber M, Weisgrau KL, Landucci G, Forthal DN, Koff WC, Poignard P, Watkins DI, Burton DR. 2010. Broadly Neutralizing Monoclonal Antibodies 2F5 and 4E10 Directed against the Human Immunodeficiency Virus Type 1 gp41 Membrane-Proximal External Region Protect against Mucosal Challenge by Simian-Human Immunodeficiency Virus SHIVBa-L. J Virol 84:1302-1313.

72. Pegu A, Yang ZY, Boyington JC, Wu L, Ko SY, Schmidt SD, McKee K, Kong WP, Shi W, Chen X, Todd JP, Letvin NL, Huang J, Nason MC, Hoxie JA, Kwong PD, Connors M, Rao SS, Mascola JR, Nabel GJ. 2014. Neutralizing antibodies to HIV-1 envelope protect more effectively in vivo than those to the CD4 receptor. Sci Transl Med 6, 243 ra88.

73. Pegu A, Borate B, Huang Y, Pauthner MG, Hessell AJ, Julg B, Doria-Rose NA, Schmidt SD, Carpp LN, Cully MD, Chen X, Shaw GM, Barouch DH, Haigwood NL, Corey L, Burton DR, Roederer M, Gilbert PB, Mascola JR, Huang Y. 2019. A Meta-analysis of Passive Immunization Studies Shows that Serum-

Neutralizing Antibody Titer Associates with Protection against SHIV Challenge. Cell Host Microbe 26:336346.e3.

74. Wu X, Yang Z-Y, Li Y, Hogerkorp C-M, Schief WR, Seaman MS, Zhou T, Schmidt SD, Wu L, Xu L, Longo NS, McKee K, O’Dell S, Louder MK, Wycuff DL, Feng Y, Nason M, Doria-Rose N, Connors M, Kwong PD, Roederer M, Wyatt RT, Nabel GJ, Mascola JR. 2010. Rational Design of Envelope Identifies Broadly Neutralizing Human Monoclonal Antibodies to HIV-1. Science 329:856-862.

75. Barouch DH, Yang Z, Kong W, Korioth-schmitz B, Sumida SM, Truitt DM, Kishko MG, Arthur JC, Miura A, Mascola JR, Letvin NL, Nabel GJ. 2005. A Human T-Cell Leukemia Virus Type 1 Regulatory Element Enhances the Immunogenicity of Human Immunodeficiency Virus Type 1 DNA Vaccines in Mice and Nonhuman Primates. J Virol 79:8828-8834.

76. Dalby A, Dauter Z, Littlechild JA. 1999. Crystal structure of human muscle aldolase complexed with fructose 1,6-bisphosphate: Mechanistic implications. Protein Sci 8:291-297.

77. Graham FL, Van der Eb A. 1973. A New Technique for the Assay of Infectivity of Human Adenovirus 5 DNA. Virology 52:456-467. 
78. Kutner RH, Zhang XY, Reiser J. 2009. Production, concentration and titration of pseudotyped HIV-1-based lentiviral vectors. Nat Protoc 4:495-505.

79. Pear WS, Nolan GP, Scott ML, Baltimore D. 1993. Production of high-titer helper-free retroviruses by transient transfection. Proc Natl Acad Sci U S A 90:8392-8396.

80. Wei X, Decker JM, Liu H, Zhang Z, Arani RB, Kilby JM, Saag MS, Wu X, Shaw GM, Kappes JC. 2002. Emergence of resistant human immunodeficiency virus type 1 in patients receiving fusion inhibitor (T-20) monotherapy. Antimicrob Agents Chemother 46:1896-1905.

81. Wei X, Decker JM, Wang S, Hui H, Kappes JC, Wu X, Salazar-Gonzalez JF, Salazar MG, Kilby JM, Saag MS, Komarova NL, Nowak MA, Hahn BH, Kwong PD, Shaw GM. 2003. Antibody neutralization and escape by HIV-1. Nature 422:307-312.

82. Platt EJ, Wehrly K, Kuhmann SE, Chesebro B, Kabat D. 1998. Effects of CCR5 and CD4 Cell Surface Concentrations on Infections by Macrophagetropic Isolates of Human Immunodeficiency Virus Type 1. J Virol 72:2855-2864.

83. Derdeyn CA, Decker JM, Sfakianos JN, Wu X, O’brien WA, Ratner L, Kappes JC, Shaw GM, Hunter E. 2000. Sensitivity of Human Immunodeficiency Virus Type 1 to the Fusion Inhibitor T-20 Is Modulated by Coreceptor Specificity Defined by the V3 Loop of gp120. J Virol 74:8358-8367.

84. Takeuchi Y, McClure MO, Pizzato M. 2008. Identification of Gammaretroviruses Constitutively Released from Cell Lines Used for Human Immunodeficiency Virus Research. J Virol 82:12585-12588.

85. Platt EJ, Bilska M, Kozak SL, Kabat D, Montefiori DC. 2009. Evidence that Ecotropic Murine Leukemia Virus Contamination in TZM-bl Cells Does Not Affect the Outcome of Neutralizing Antibody Assays with Human Immunodeficiency Virus Type 1. J Virol 83:8289-8292.

86. Ozaki DA, Gao H, Todd CA, Greene KM, Montefiori DC, Sarzotti-Kelsoe M. 2012. International technology transfer of a GCLP-compliant HIV-1 neutralizing antibody assay for human clinical trials. PLoS One 7, e30963. 


\section{Supplementary Information}

\section{Purification method impacts D5's neutralization potency}

After completing the initial neutralization screens of the D5 variants, a more in-depth neutralization profile was determined for D5_AR compared to D5. This profiling involved testing the constructs' neutralization potency against various viruses and in various antibody formats. Notably, we found that the manner of purification and concentration of antibodies impacts the observed neutralization activity of the antibody. In our initial neutralization screens, we did not include a size exclusion chromatography (SEC) purification step after Protein A purification: we immediately spin-concentrated the elution and filtered the concentrated antibody for use in neutralization assays (Materials and Methods). For the in-depth neutralization analysis, we further purified antibodies via SEC after Protein A purification. After SEC purification, we concentrated the protein using spin concentrators. These $\mathrm{ID}_{50}$ values (Figure 3 ) differed from the values that we previously measured (Table 1) when the antibodies were not SEC-purified (SEC-purified preparations had a 1.5 -fold decrease in $\mathrm{ID}_{50}$ for $\mathrm{D} 5$ and a 2.3 -fold decrease in $\mathrm{ID}_{50}$ for D5_AR) (Supplemental Figure 3). A side-by-side comparison revealed that there was indeed a difference in neutralization for D5-AR (Supplemental Figure 3A), although neutralization was still enhanced compared to D5. UV traces from SEC indicated that aggregates may explain this difference in reported neutralization (Supplemental Figure 3B), which likely explains the discrepancy in reported ID 50 values for HXB2 in Table 1 and Figure 3 of the main text. 


\title{
Supplemental Figures and Tables
}

\begin{abstract}
A
D5

VH CDR 1

VH CDR 2

D5 AR

QVQLVQSGAEVRKPGASVKVSCKASGDTFSSYAISWVRQAPGQGLEWMGGIIPIFGTANYAQKF $Q$

65

D5_H100

QVQLVQSGAEVRKPGASVKVSCKASGDTFSSYAISWVRQAPGQGLEWMGSIIPLFGTAAYAQKFQ

D5_H010

QVQLVQSGAEVRKPGASVKVSCKASGDTFNIWQYSWVRQAPGQGLEWMGGIIPIFGTANYAQKFQ

QVQLVQSGAEVRKPGASVKVSCKASGDTFSSYAISWVRQAPGQGLEWMGSIIPLFGTAAYAQKFQ

D5_H110

QVQLVQSGAEVRKPGASVKVSCKASGDTFSSYAISWVRQAPGQGLEWMGGIIPIFGTANYAQKFQ

D5_H101

QVQLVQSGAEVRKPGASVKVSCKASGDTFNIWQYSWVRQAPGQGLEWMGSIIPLFGTAAYAQKEQ

65

D5_H111

QVQLVQSGAEVRKPGASVKVSCKASGDTFNIWQYSWVRQAPGQGLEWMGGIIPIFGTANYAQKFQ

QVQLVQSGAEVRKPGASVKVSCKASGDTFNIWQYSWVRQAPGQGLEWMGSIIPLFGTAAYAQKFQ 65

D5 VH CDR 3

D5_AR GRVTITADESTSTAYMELSSLRSEDTAIYYCARDNPTLLGSDYWGKGTLVTVSS

119

D5 $\mathrm{H} 100$ GRVTITADESTSTAYMELSSLRSEDTAIYYCARDNPTFGAADSWGKGTLVTVSS

119

GRVTITADESTSTAYMELSSLRSEDTAIYYCARDNPTLLGSDYWGKGTLVTVSS 119

D5_H010

GRVTITADESTSTAYMELSSLRSEDTAIYYCARDNPTLLGSDYWGKGTLVTVSS

119

D5_H001

GRVTITADESTSTAYMELSSLRSEDTAIYYCARDNPTFGAADSWGKGTLVTVSS

119

D5_H110

GRVTITADESTSTAYMELSSLRSEDTAIYYCARDNPTLLGSDYWGKGTLVTVSS

119

D5_H101

GRVTITADESTSTAYMELSSLRSEDTAIYYCARDNPTFGAADSWGKGTLVTVSS

119

D5_H111

GRVTITADESTSTAYMELSSLRSEDTAIYYCARDNPTFGAADSWGKGTLVTVSS

119

B

D5

VL CDR 1

VL CDR 2

D5_L001

DIQMTQSPSTLSASIGDRVTITCRASEGIYHWLAWYQQKPGKAPKLLIYKASSLAS GAPSRFSGS 65 DIQMTQSPSTLSAS IGDRVTITCRASEGIYHWLAWYQQKPGKAPKLLIYKASSLASGAPSRFSGS 65

D5

VL CDR 3

D5_L001

GSGTDFTLTISSLQPDDFATYYCQQYSNYPLTFGGGTKLEIK

107

GSGTDFTLTISSLQPDDFATYYCQQYGYSENTFGGGTKLEIK

107

Supplemental Figure 1: Sequences of D5 variant variable heavy and variable light chain regions.

(A) Sequence alignment of variable heavy (VH) chain sequences of D5 variants (IGHV1-69 germline). (B) Sequence alignment of variable light (VL) chain sequence of D5 variants (IGKV1-5 germline). Bold font denotes complementarity-determining regions and red letters highlight amino acid changes from wild-type D5.
\end{abstract}




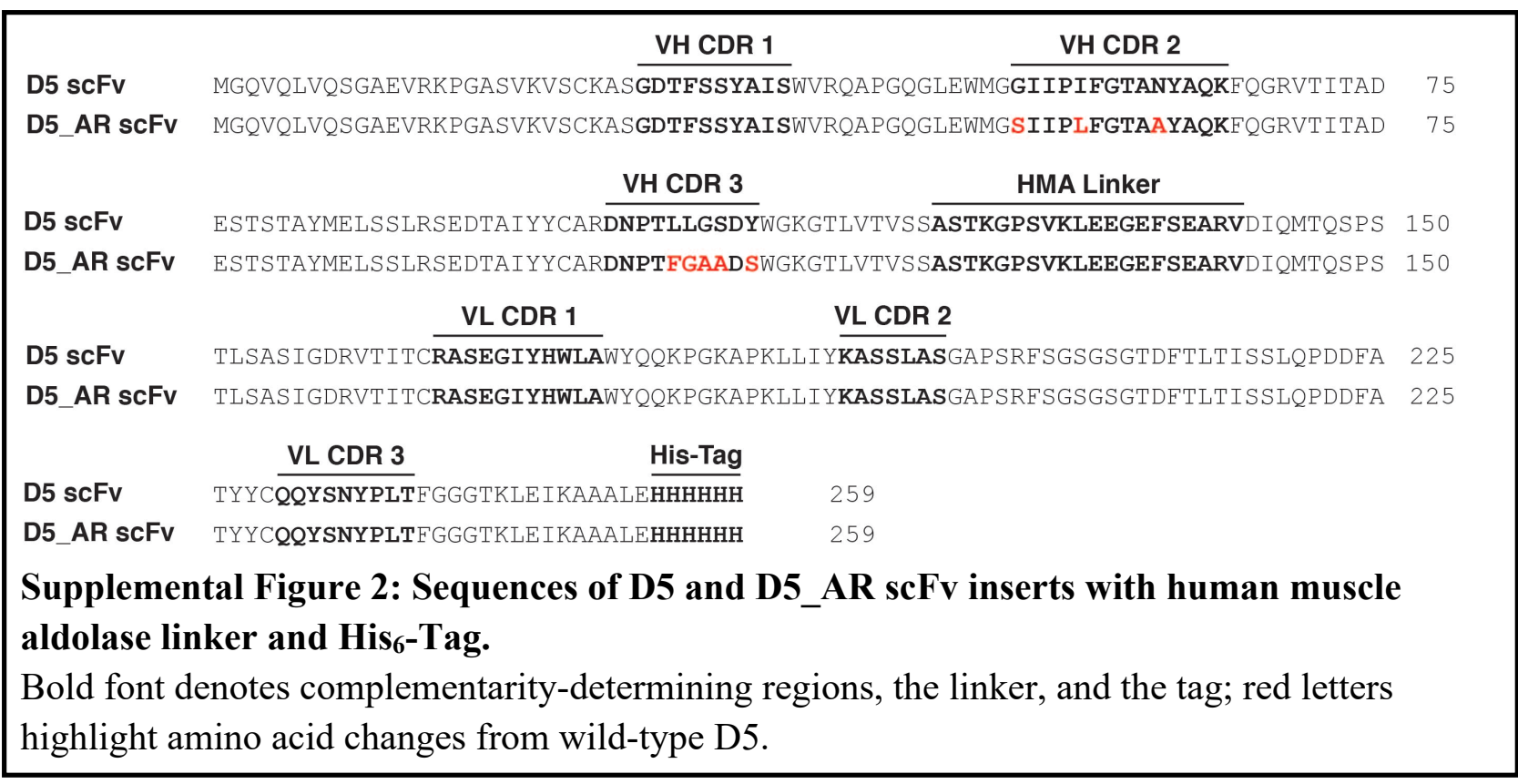
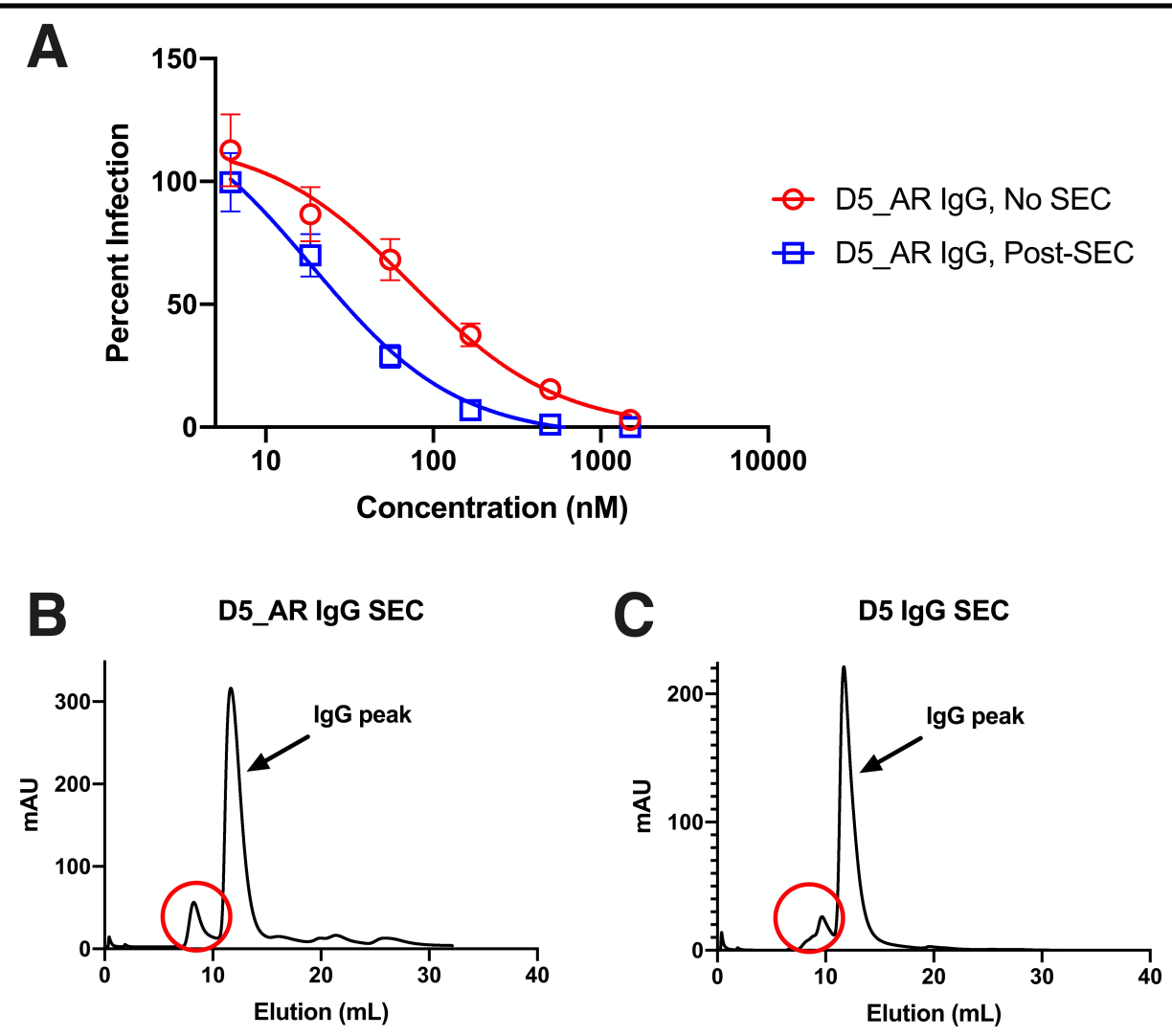

Supplemental Figure 3: Purification via size exclusion chromatography (SEC) impacts the neutralization potency of $D 5$ _AR and reveals possible aggregation.

(A) After purification by gel filtration, D5_AR IgG preparations demonstrated enhanced neutralization activity. Each data point represents the mean with standard error of mean $(n=2)$.

(B and C) UV traces from SEC reveal possible protein aggregates (circled in red) for both D5 and D5_AR IgG. 


\begin{tabular}{|c|c|c|c|c|}
\hline \multirow[b]{2}{*}{ D5 IgG Variant } & \multicolumn{2}{|c|}{ Montgomery et al. (24) } & \multicolumn{2}{|c|}{ This work } \\
\hline & $I_{50}(n M)$ & Fold Change & $I_{50}(n M)$ & Fold Change \\
\hline D5 & $424 \pm 150$ & 1.0 & $320 \pm 28$ & 1.0 \\
\hline D5_H100_LO & $209 \pm 62$ & 2.0 & $210 \pm 64$ & 2.5 \\
\hline D5_H010_L0 & $195 \pm 77$ & 2.2 & $240 \pm 32$ & 2.5 \\
\hline D5_H001_LO & $362 \pm 68$ & 1.2 & $360 \pm 83$ & 1.8 \\
\hline D5_H000_L1 & $147 \pm 31$ & 2.9 & $220 \pm 17$ & 2.3 \\
\hline \multicolumn{5}{|c|}{$\begin{array}{l}\text { Supplemental Table 1: Single-CDR mutants neutralize pseudotyped HIV-1 HXB2 in a } \\
\text { fashion consistent with the report of Montgomery et al. }(24) \text {. } \\
\text { The ID } 50 \text { for this work is represented by the geometric mean and standard error of the mean of } \\
\text { replicate experiments ( } \mathrm{n}=2 \text { ). For each infection assay, the fold enhancement versus D5 was } \\
\text { calculated (ID } 50 \text {, D5 / ID } 50 \text {, D5 variant); reported fold enhancement is the geometric mean }(\mathrm{n}=2) \text {. }\end{array}$} \\
\hline
\end{tabular}

